\title{
Use of Urea to Correct Immature Urban Composts for Agricultural Purposes
}

\author{
Fernando Madrid, José M. Murillo, Rafael López, and \\ Francisco Cabrera
}

Instituto de Recursos Naturales y Agrobiologia, CSIC, Aptdo. 1052, 41080 Sevilla, Spain

\section{ABSTRACT}

Municipal solid waste composts are often inadequately stabilized for agricultural purposes. In addition, compost quality may be even more reduced by loss of nitrogen $(\mathrm{N})$ during the composting process. We have utilized a compost with a high content of soluble sugars (1l $\mathrm{mg} \mathrm{g}^{-1}, \mathrm{DM}$, indicating immaturity) and a low $\mathrm{N}$ concentration $(0.95 \%, \mathrm{DM})$. The compost had a low level of heavy metals. Results obtained in a germination bioassay conducted with cress, ryegrass and sunflower in a compost-sand mixture reflected the immaturity of the compost. Such composts should be forified with $\mathrm{N}$ (in a complete fertilizer, when possible), at the same time avoiding an intimate contact with the soil (e.g., plowing down). When the compost (and raw wastes and wastes at the 4th week of composting) was mixed with a soil at a heavy rate $(2.5 \% \mathrm{w}: \mathrm{w})$, ryegrass seedling emergence in pots was not affected, but the plantlets' fresh weight in the compost treatment was signiticantly lower than that in the control (soil) and lower than that in the raw wastes, probably due to the lower $\mathrm{N}$ concentration. As expected, plantlet fresh weight was notably increased by the combination of compost and wastes with a complete fertilizer. The application of compost in combination with a complete fertilizer or urea did not affect either dry matter production or nutrient uptake of ryegrass, 
despite the combination's being applied just at sowing (in pots). Results obtained in these experiments indicate that combining immature composts with urea [supplemented with phosphorus $(\mathrm{P})$ and potassium $(\mathrm{K})$, when possible] at a ratio of about $50: 1$ (about $200 \mathrm{~kg}$ urea per $10 \mathrm{t}$ compost) could be sufficient to prevent negative results in crop establishment. Such practices could contribute to overcoming the limited fertilizing capacity of the composts.

\section{INTRODUCTION}

The benefits of adding manure and composts to soils are extensively reported (De Bertoldi et al., 1987; Barker, 1997). However, negative effects of using urban composts in agriculture, derived from their pollution capacity and/or immaturity, have also been detected (De Haan, 1981; Mathur et al., 1993; Déportes et al., 1995). Thus, the regulation of compost quality, besides inerts and pollutants (metals, $\mathrm{PCB}$ ), frequently calls for the control of additional requirements for compost stability. For this purpose, indicators such as volatile solids destruction, spontaneous heating, $\mathrm{O}_{2}$ uptake rates, toxin production, $\mathrm{C} / \mathrm{N}$ ratio, seed germination and growth tests, and redox potential have been cited by Gies (1992). If no determination of stability is made, the compost product (inerts and pollutants within permissible levels) must be cured for a six month period (Gies, 1992).

However, as pointed out by Zucconi et al. (1985), many of the urban composts used in agriculture are not completely stabilized, because the time required for complete stabilization is often incompatible with the space, handling, equipment and other requirements of industry. This may lead to agricultural problems, being the most serious ' $\mathrm{N}$ rob' in plants planted immediately after treating the soil with immature composts (Smith, 1996). Moreover, problems derived from a restriction of $\mathrm{O}_{2}$ supply for plants may arise when composts are plowing down into compacted soils (Avnimelech et al., 1993). Nitrogen application would be desirable in such cases, especially when an adequate separation between planting and compost loading were troublesome for farmers.

Even when mature, most composts contain relatively low levels of nutrients, with a low rate of mineralization, so that the compost dose needed to meet crop requirements may be too large. This could be a problem for most farmers, because even if such a large rate of compost application were economically viable, it would be outside the limits set by current legislation in many countries (Murillo et al., 1995a; Sikora, 1996). Normal doses of composts must therefore be fortified with complete fertilizers. As pointed out by Sikora (1996), blending residues or composts with fertilizers is an appealing alternative which (a) uses residues at lower rates, (b) reduces the amount of inorganic fertilizer applied to soils, and (c) reduces the accumulation of non-nutrient ingredients in soils. If, moreover, this practice avoids the risks of ' $\mathrm{N}$ rob' and of a restricted $\mathrm{O}_{2}$ supply for plants, it is obvious that fortified compost product shows promise as a fertilizer (Hileman, 1982). 
The present paper deals with the effect of $\mathrm{N}$ application on ryegrass growth, when a heavy rate of an immature compost is mixed with the soil. The effect (on the dry matter production and composition of a ryegrass) of applying increasing doses of urea together with the compost is also studied to obtain information about reasonable compost:urea ratios for the best use of these immature composts.

\section{MATERIALS AND METHODS}

\section{Analyses of the Wastes, Compost, and Plant Material}

The urban compost from the 'Villarrasa' facility (Huelva, Spain: fraction $<10 \mathrm{~mm}$, available for sale) was utilized as organic fertilizer. A complete $15 \mathrm{~N}-15 \mathrm{P}_{2} \mathrm{O}_{5}-15 \mathrm{~K}_{2} \mathrm{O}$ fertilizer and urea ( $46 \% \mathrm{~N}$, supplemented with $\mathrm{P}$ and $\mathrm{K}$ ) were used to fortify the compost. The composts were obtained by a monitored bio-oxidative process taking about 10 to 12 weeks. Ten subsamples were taken at random from several piles of the final compost, in order to obtain a composite sample from each pile. Samples from the initial, raw wastes (fraction $<60 \mathrm{~mm}$ ) and those from wastes at the 4 th week of composting (fraction $<60 \mathrm{~mm}$ ) were also sampled. Raw wastes, wastes (4th week), and the final compost will be referred to as $\mathrm{W}_{0}, \mathrm{~W}_{4}$, and $\mathrm{C}$, respectively, hereafter.

Samples were dried at $70^{\circ} \mathrm{C}$ for $72 \mathrm{~h}$, and visible inerts $(>2 \mathrm{~mm})$, such as glass and plastics (fraction that usually ranges from $1-2 \%$ in the final compost, but up to $50 \%$ in the raw wastes) were removed. Dried samples were then ground to a particle size $<2 \mathrm{~mm}$ to avoid heterogeneity for analysis. The $\mathrm{pH}$ and electrical conductivity were measured by suspending the sample in water in the proportion 1:5 (w:v). Nitrogen of wastes and compost (and plant material) was determined by Kjeldahl digestion, and total organic matter by mineralization at $500^{\circ} \mathrm{C}$. The cation exchange capacity was determined in the compost according to Harada and Inoko (1980). Soluble sugars in wastes and compost were extracted with water and determined by the phenol-sulphuric acid method (Ashwell, 1966), and total lipids were determined by extraction with a dichloromethane:methanol solution.

Nutrients (compost and plant material) and heavy metals (compost) were extracted by treating the ashes, obtained by mineralization with concentrated $\mathrm{HCl}$ on a hot plate. Potassium and sodium ( $\mathrm{Na}$ ) were determined by flame emission, and calcium (Ca), magnesium $(\mathrm{Mg})$, iron $(\mathrm{Fe})$, manganese $(\mathrm{Mn})$, zinc $(\mathrm{Zn})$, copper $(\mathrm{Cu})$, chromium $(\mathrm{Cr})$, nickel $(\mathrm{Ni})$, lead $(\mathrm{Pb})$, and cadmium (Cd) by atomic absorption spectrometry. Phosphorus was determined by colorimetric determination using the phosphovanadomolybdic complex.

\section{Bioassays of Germination and Seedling Emergence}

The test was carried out for cress (Lepidium sativum L.), ryegrass (Lolium multiflorum Lam. cv. 'Tewera') and sunflower (Helianthus annus L. cv. 'Hysum 33') at rom temperature, using a end-commost tor wastes. $\left.W_{f_{i}} W_{i}\right)$ mixture (1:1). 
Compost and wastes were homogenized by grinding to a particle size $<2 \mathrm{~mm}$. Twenty Petri dishes (diameter: $5.5 \mathrm{~cm}$ ), containing either the mixture or only sand (controls), were prepared for each species ( 5 seeds for cress and ryegrass, and 4 seeds for sunflower). The dishes were moistened and lined with a filter paper. Germinated seeds and root length were recorded after $72 \mathrm{~h}$ and expressed as a percentage of the control. A germination index was obtained as a product of the two percentages dividing by 100 .

Seedling emergence and performance of ryegrass in a representative soil of SW Spain (a light yellowish-brown sandy clay loam soil, $\mathrm{pH} 7.7, \mathrm{CaCO}_{3} 30 \%$ ) was also tested in the greenhouse using wastes $\left(\mathrm{W}_{0}, \mathrm{~W}_{4}\right)$, and the compost $(\mathrm{C})$, applied alone or fortified with the inorganic 15-15-15 fertilizer (IF). Compost (or wastes)soil mixtures at $2.5 \%$ [w:w, $6.25 \mathrm{~g} \mathrm{C}$ (or wastes) per pot] were used in pots of $300 \mathrm{~g}$ capacity (treatments $\mathrm{C}, \mathrm{W}_{0}, \mathrm{~W}_{4}$, respectively). Treatment $\mathrm{IF}(0.42 \mathrm{~g} \mathrm{IF}$ per pot) was prepared so as to apply roughly the same amount of $\mathrm{N}$ per pot as that added in treatments $\mathrm{C}_{,} \mathrm{W}_{0}$ and $\mathrm{W}_{4}$ (about $0.25 \mathrm{~g} \mathrm{~N} \mathrm{~kg}^{-1}$ soil).

Treatments $\mathrm{W}_{0}+\mathrm{IF}, \mathrm{W}_{4}+\mathrm{IF}$, and $\mathrm{C}+\mathrm{IF}$ were also prepared by adding $\mathrm{N}$ at a rate of $0.25 \mathrm{~g} \mathrm{~kg}^{-1}\left[0.21 \mathrm{~g} \mathrm{IF} \mathrm{pot}^{-1}\right.$ and $3.125 \mathrm{~g}$ compost (waste) pot $\left.^{-1}\right]$. A control was prepared without any fertilizer or waste. Before preparing the test, soil, wastes, and compost were ground to pass a $2-\mathrm{mm}$ sieve for homogenization. A randomized, complete block design with six replicates per treatment and 10 seeds of ryegrass per pot was prepared. Seedling emergence was monitored for 20 days. The five most-developed plantlets of each pot were cut 15 days after sowing and the mean fresh above-ground plantlet weight was immediately obtained using an analytical balance. The other 5 plants were discarded. Three months after the first sowing (bare pots were periodically moistened by subirrigation), each pot was sown again with 10 seeds of ryegrass to obtain the mean fresh plantlet weight 30 days after this second sowing.

\section{Compost Correction with Urea and Inorganic Fertilizer (IF)}

Pots of $2 \mathrm{~kg}$ capacity, and the same soil used for the mixtures of the seedling emergence assay ( $1.5 \mathrm{~kg}$ per each pot), were used in this experiment, in which $\mathrm{N}$ was also applied at a rate of $0.25 \mathrm{~g} \mathrm{~kg}^{-1}$. Compost was applied at a rate $37.5 \mathrm{~g} \mathrm{pot}^{-1}$ $(2.5 \% \mathrm{w}: \mathrm{w}), \mathrm{IF}$ at a rate of $2.52 \mathrm{~g} \mathrm{pot}^{-1}$, and urea (treatment $\left.\mathrm{U}\right)$ at a rate of $0.81 \mathrm{~g} \mathrm{pot}^{-1}$. Rating of compost, IF and urea was reduced to one half in treatments $\mathrm{C}+\mathrm{IF}(\mathrm{C}$ : 18.75 $\left.\mathrm{g} \mathrm{pot}^{-1}, \mathrm{IF}: 1.26 \mathrm{~g} \mathrm{pot}^{-1}\right)$ and $\mathrm{C}+\mathrm{U}\left(\mathrm{C}: 18.75 \mathrm{~g} \mathrm{pot}^{-1}, \mathrm{U}: 0.40 \mathrm{~g} \mathrm{pot} \mathrm{t}^{-1}\right)$. Soil without any fertilizer was used as a control. Soil and compost were ground to particle size $<2 \mathrm{~mm}$ to avoid heterogeneity. A randomized, complete block design with four replicates per treatment and one gram of seeds of ryegrass per pot was prepared. Fresh and dry matter (drying at $70^{\circ} \mathrm{C}$ for $48 \mathrm{~h}$ ) production per pot was obtained 40 days after sowing and 60 days after the first cut. Plant moisture was obtained by drying a representative sample at $105^{\circ} \mathrm{C}$ for two hours. After the drying at $70^{\circ} \mathrm{C}$, plant material was ground for analysis. 


\section{Compost Correction with Increasing Doses of Urea}

This assay was conducted to study the effect of three compost:urea ratios on the ryegrass growth. Urea was selected as a cheap source of $\mathrm{N}$. Pots of $2 \mathrm{~kg}$ capacity were again used. For avoiding compaction and ensure an adequate oxygen supply, a soil-perlite mixture (5:1, w:w) was used as substrate (control) (750 $\mathrm{g}$ of substrate per each pot). Soil was ground to particle size $<2 \mathrm{~mm}$, but the compost (fraction $<10 \mathrm{~mm}$ ) was applied without grinding, at a rate of $1.5 \%(11.25 \mathrm{~g}$ pot $\left.^{-1}\right)$. Compost $(1.5 \%)$ was combined with increasing doses of urea $(46 \% \mathrm{~N})$ in treatments: $\mathrm{C}+\mathrm{U}_{1}\left(0.245 \mathrm{~g}\right.$ urea pot $\mathrm{t}^{-1}$, about $0.30 \mathrm{~g} \mathrm{~N} \mathrm{~kg}^{-1}$ substrate, in total $) ; \mathrm{C}+\mathrm{U}_{2}$ (0.49 $\mathrm{g}$ urea pot $^{-1}, 0.45 \mathrm{~g} \mathrm{~N} \mathrm{~kg}^{-1}$ substrate); and $\mathrm{C}+\mathrm{U}_{3}\left(0.735 \mathrm{~g}^{2}\right.$ urea pot ${ }^{-1}, 0.60 \mathrm{~g} \mathrm{~N}$ $\mathrm{kg}^{-1}$ substrate). Compost:urea ratios were, respectively, about 50:1, 25:1, and 12.5:1 in these treatments. Treatments applying only urea $\left(U_{1}, U_{2}\right.$, and $\left.U_{3}\right)$ were also established for comparison. Urea was supplemented with $\mathrm{P}\left(0.247 \mathrm{~g} \mathrm{pot}^{-1}\right.$ of superphosphate, $\left.35 \% \mathrm{P}_{2} \mathrm{O}_{5}\right)$ and $\mathrm{K}\left(0.225 \mathrm{~g}\right.$ pot $^{-1}$ of potassium sulphate, $\left.54 \% \mathrm{~K}_{2} \mathrm{O}\right)$ in all the treatments.

A randomized, complete block design with four replicates per treatment and one gram of seeds of ryegrass per pot was prepared. Fresh and dry matter production per pot was obtained 40 days after sowing and in two further cuts carried out at monthly intervals.

\section{Statistical Analyses}

Data analysis was conducted performing analysis of variance. Mean separations were determined by the Tukey test $(\mathrm{P}<0.05)$.

\section{RESULTS AND DISCUSSION}

\section{Compost Characterization}

Biogenic waste composts have clear advantages for agricultural use, as has been shown in the literature (Fricke et al., 1989; Vogtmann et al., 1993). However, many countries do not have adequate facilities for producing biogenic composts at the rate and price required by local agriculture. A scrupulous separation process at the composting facilities could largely overcome the risks presented by heavy metals and other constraints. Composts produced in facilities receiving wastes from villages, such as the compost used here, may also contain reasonably low amounts of heavy metals, as shown in Table 1 . Heavy metal concentrations are lower, except $\mathrm{Cr}$, than the permissible levels indicated by Zucconi and De Bertoldi (1987). Copper and $\mathrm{Cr}$ contents are higher than the more restrictive levels of Gies (1992) and Vogtmann et al. (1993) with $\mathrm{Pb}$ in the upper limit of these ranges. In fact, concentrations of most heavy metals in the compost from the Villarrasa facility correspond to composts of high quality, according to the data of Genevini et al. (1997). 
TABLE 1. Analysis of the compost utilized (particle size $<10 \mathrm{~mm}$, mean values of 8 determinations), and normal ranges for the urban composts from the 'Villarrasa' facility ( 15 batches). Values specified in the literature are also shown (samples were ground in all cases to a particle size $<2 \mathrm{~mm}$ for homogenization).

\begin{tabular}{|c|c|c|c|c|c|}
\hline Property & Compost & Range & $\mathbf{A}$ & B & $\mathrm{C}$ \\
\hline Total organic matter $\%$ & 38 & $23-42$ & $30-35$ & & $27.2-39.6$ \\
\hline $\mathrm{N} \%$ & 0.95 & $0.55-1.35$ & $>0.6$ & & $0.88-1.47$ \\
\hline $\mathrm{pH}-\mathrm{H}_{2} \mathrm{O}$ (compost/water $1 / 5$ ) & 6.9 & $6.3-7.8$ & $5.5-8.0$ & & $7.2-7.8$ \\
\hline $\mathrm{C} / \mathrm{N}$ & 22 & $13-25$ & $<22$ & & $12.3-20.0$ \\
\hline $\begin{array}{l}\text { Electrical conductivity } \mathrm{dS} \mathrm{m}^{-1} \\
\text { (compost/water } 1 / 5 \text { ) }\end{array}$ & 7.6 & $4.7-9.0$ & & & \\
\hline $\begin{array}{l}\text { Cation exchange capacity } \\
\mathrm{cmol}_{\mathrm{c}} \mathrm{kg}^{-1} \\
\text { (on organic matter basis) }\end{array}$ & 72.9 & $57.6-82.7$ & & & \\
\hline $\mathrm{P}_{2} \mathrm{O}_{5} \%$ & 0.89 & $0.58-1.04$ & $0.5-0.9$ & & $0.38-0.80$ \\
\hline $\mathrm{K}_{2} \mathrm{O} \%$ & 0.90 & $0.40-1.28$ & $0.2-0.8$ & & $0.63-1.37$ \\
\hline $\mathrm{CaO} \%$ & 5.32 & $3.30-9.09$ & $>2.0$ & & $2.14-5.50$ \\
\hline $\mathrm{MgO} \%$ & 0.45 & $0.28-0.85$ & $>0.3$ & & $0.38-1.09$ \\
\hline $\mathrm{Na} \%$ & 0.63 & $0.28-0.88$ & & & \\
\hline $\mathrm{Fe} \%$ & 1.05 & $0.50-1.40$ & & & \\
\hline $\mathrm{Cu} \mathrm{mg} \mathrm{kg} \cdot$ & 180 & $93-204$ & 300 & 60 & 100 \\
\hline $\mathrm{Zn} \mathrm{mg} \mathrm{kg-1}$ & 320 & $185-374$ & 1000 & 500 & 400 \\
\hline $\mathrm{Mn} \mathrm{mg} \mathrm{kg}^{-1}$ & 155 & $119-366$ & & & \\
\hline $\mathrm{Cr} \mathrm{mg} \mathrm{kg}^{-1}$ & 190 & $52-267$ & 150 & 50 & 100 \\
\hline $\mathrm{Ni} \mathrm{mg} \mathrm{kg}^{-1}$ & 32 & $23-41$ & 50 & 60 & 50 \\
\hline $\mathrm{Pb} \mathrm{mg} \mathrm{kg}$ & 152 & $58-187$ & 750 & 150 & 150 \\
\hline $\mathrm{Cd} \mathrm{mg} \mathrm{kg}$ & $<1$ & $<1$ & 5 & 3 & 1.5 \\
\hline
\end{tabular}

'A: Specifications for solid waste composts: recommended limits for heavy metals and desirable levels of nutrients, inerts and organic matter for ma:ketable products (Zucconi and De Bertoldi, 1987).

'B: Specifications for regulating compost quality in Ontario (Gies, 1992).

${ }^{3} \mathrm{C}$ : Levels of organic matter, $\mathrm{pH}$, and nutrients for biogenic waste compost and limits for heavy metals established by BGGK (Vogtmann et al., 1993).

Heavy metals apart, low compost quality can also result from an incomplete stabilization, which can make the compost inappropriate for agricultural use without adequate evolution in the soil prior to planting. Data on soluble sugars content (Table 2), seem to indicate that the compost contained non-stabilized substances, and a high content of total lipids. Table 2 also shows a loss of $\mathrm{N}$ during the composting process [also shown by Soliva et al. (1993) in other Spanish facilities], 
TABLE 2. Evolution of selected properties during composting in the 'Villarrasa' facility $\left(W_{0}\right.$, wastes; $W_{4}$, fourth week of composting; $C$, final compost (particle size $<10 \mathrm{~mm}$ ). Samples were ground in all cases to a particle size $<2 \mathrm{~mm}$ for homogeneization (mean values of 8 determinations).

\begin{tabular}{lccccc}
\hline Sample & $\begin{array}{c}\text { Organic matter } \\
(\%)\end{array}$ & $\mathrm{C} / \mathrm{N}$ & $\mathrm{N}(\%)$ & $\begin{array}{c}\text { Soluble sugars } \\
\left(\mathrm{mg} \mathrm{g}^{-1}\right)\end{array}$ & $\begin{array}{c}\text { Total lipids } \\
(\%)\end{array}$ \\
\hline $\mathrm{W}_{0}$ & 46 & 17 & 1.38 & 15 & 5.9 \\
$\mathrm{~W}_{4}$ & 45 & 22 & 1.06 & 11 & 7.9 \\
$\mathrm{C}$ & 38 & 22 & 0.95 & 11 & 8.1 \\
\hline
\end{tabular}

which could enhance a possible ' $\mathrm{N}$ rob' in plants (besides possible problems of $\mathrm{O}_{2}$ restriction, derived from its immaturity) if the compost were applied close to planting and/or plowing down into the soil.

\section{Bioassays of Germination and Seedling Emergence}

Chemical analyses apart, bioassays of instant toxicity should always be tested with these kinds of compost to avoid unexpected negative effects on plant development, especially at the plantlet stage. A simple germination bioassay in a sand-compost mixture may be sufficiently informative (Murillo et al., 1995b). This bioassay was carried out, and showed the immaturity of the urban compost used (Table 3). Wastes before composting completely inhibited cress, ryegrass and sunflower germination. After four weeks of composting (treatment $\mathrm{W}_{4}$ ), only the sunflower seeds showed some germination capacity, but with an extremely low root elongation, which would corroborate the assertion of Zucconi et al. (1981) that toxicity during composting was strictly associated with the initial 3-4 weeks, and subsequently decreased rapid: $f$, although it had not completely disappeared after two months (residual toxicity).

Finally, the compost obtained (treatment $C$ ) completely inhibited the germination of cress and ryegrass. Only sunflower germinated to a certain extent, but with very low root elongation. This showed immaturity of the compost, as symptoms of toxicity are more pronounced at an early stage of root growth (ISTA, 1985), and can certainly cause root shortening, even at low concentrations (Zucconi et al., 1985). The GI for sunflower was thus extremely low, despite the germination percentage's reaching a reasonably high value in relation to the control (Table 3 ).

When this low-quality compost was incorporated (mixed) into a calcareous soil at a high rate $(2.5 \%, \mathrm{w}: \mathrm{w})$, ryegrass seedling emergence was not affected, despite the germination sensitivity of Lolium genus (Murillo et al., 1993). Seedling emergence in soil was not only unaffected by $C$, but also by $W_{0}$ and $W_{4}$ treatments (Table 4 ). The negative effect of wastes and compost (treatments $\mathrm{W}_{0}, \mathrm{~W}_{4}$, and C) 
TABLE 3. Germination bioassay for cress, ryegrass, and sunflower in a compost/sand mixture ( $1 / 1$, mean values at 72 hours).

\begin{tabular}{llccc}
\hline Specics & Treatment & $\begin{array}{c}\text { Germination } \\
\text { (\% of control) }\end{array}$ & $\begin{array}{c}\text { Root length } \\
(\mathrm{mm})\end{array}$ & $\begin{array}{c}\text { Germination index } \\
(\%)\end{array}$ \\
\hline Cress & Control & - & 19.9 & - \\
& $\mathrm{W}_{0}$ & 0 & 0 & 0 \\
& $\mathrm{~W}_{4}$ & 0 & 0 & 0 \\
& $\mathrm{C}$ & 0 & 0 & 0 \\
\multirow{5}{*}{ Ryegrass } & Control & - & 10.8 & - \\
& $\mathrm{W}_{0}$ & 0 & 0 & 0 \\
& $\mathrm{~W}_{4}$ & 0 & 0 & 0 \\
& $\mathrm{C}$ & 0 & 0 & 0 \\
Sunflower & Control & - & 7.5 & - \\
& $\mathrm{W}_{0}$ & 0 & 0 & 0 \\
& $\mathrm{~W}_{4}$ & 18.2 & 0.2 & 0.5 \\
& $\mathrm{C}^{4}$ & 63.6 & 0.5 & 4.7 \\
\hline
\end{tabular}

TABLE 4. Mean values of seedling emergence of ryegrass in soil (1st sowing, day 21) and fresh weights of the ryegrass plantlets (above-ground part) of the first sowing (day 15) and of the second (day 30), carried out in the same pots three months after the first sowing.

\begin{tabular}{|c|c|c|c|}
\hline \multirow[t]{2}{*}{ Treatments } & \multirow{2}{*}{$\begin{array}{l}\text { Seedling emergence } \\
\text { (\% of the control) }\end{array}$} & \multicolumn{2}{|c|}{ Plantlets weight $(\mathrm{mg})$} \\
\hline & & first sowing & second sowing \\
\hline Control & $100 a^{*}$ & $49.4 \mathrm{c}$ & $49.4 \mathrm{bc}$ \\
\hline IF & $104 a$ & $44.1 \mathrm{cb}$ & $83.0 \mathrm{~d}$ \\
\hline $\mathrm{W}_{0}$ & $100 \mathrm{a}$ & $25.6 \mathrm{a}$ & $58.8 \mathrm{c}$ \\
\hline $\mathrm{W}_{0}+\mathrm{IF}$ & $100 \mathrm{a}$ & $45.4 \mathrm{c}$ & $121.6 \mathrm{ef}$ \\
\hline$W$ & $112 \mathrm{a}$ & $22.8 \mathrm{a}$ & $38.3 \mathrm{ab}$ \\
\hline $\mathrm{W}_{4}+\mathrm{IF}$ & $112 a$ & $42.7 \mathrm{cb}$ & $111.3 \mathrm{e}$ \\
\hline $\mathrm{C}$ & $100 \mathrm{a}$ & $21.0 \mathrm{a}$ & $25.5 \mathrm{a}$ \\
\hline $\mathrm{C}+\mathrm{IF}$ & $108 \mathrm{a}$ & $37.3 b$ & $132.4 \mathrm{f}$ \\
\hline
\end{tabular}

*Values followed by the same letter in the same column do not differ significantly $(\mathrm{P}<0.05)$. 
was shown by the plantlets' fresh weight, which was, in general, significantly lower than that of the control and, of course, that obtained in treatments IF, $\mathrm{W}_{0}+$ IF, $\mathrm{W}_{4}+\mathrm{IF}$, and $\mathrm{C}+\mathrm{IF}$ for the two sets of plantlets generated (Table 4).

In the first sowing, however, the increases in plantlet weight caused by treatments $\mathrm{W}_{0}+\mathrm{IF}, \mathrm{W}_{4}+\mathrm{IF}$, and $\mathrm{C}+\mathrm{IF}$ could only be due to the reduction in the concentration of the wastes and compost (from $2.5 \%$ to $1.25 \%$ ), because at this time ( 15 days after establishing treatments) the inorganic fertilizer did not seem to have had any marked effect on plantlet growth, as inferred from results obtained in treatments including IF. The positive effect of these treatments, especially those including wastes and the compost, was evident in the one-month plantlets of the second sowing (Table 4 ). The heavy application of compost ( $2.5 \%$, w:w, treatment C) was still restricting plantlet growth, despite its having been four months in the soil.

Treatment $C$ tended to produce plantlets with even lower weight than those of $\mathrm{W}_{0}$ and $\mathrm{W}_{4}$ treatments. The highest weights in these three treatments corresponded to $\mathrm{W}_{0}$, with a significant difference in relation to $\mathrm{C}$ in the second sowing (Table 4). This could be due, at least in part, to the comparatively high $N$ concentration of the raw wastes (Table 2), which could make their evolution in the soil favorable for plantlets, which in the second sowing achieved a higher weight (mean value of $58.8 \mathrm{mg}$ plantlet $\mathrm{t}^{-1}$ ) than the control (mean value of $49.4 \mathrm{mg} \mathrm{plantlet}^{-1}$ ).

\section{Compost Correction: Urea 'Versus' a Complete Fertilizer in Ryegrass Growth and Nutrition}

An adequate $\mathrm{N}$ supply may overcome, at least partially, both the risk of a restriction in $\mathrm{O}_{2}$ supply, being noticeable when using well particulated composts with low content of visible inerts (as is that studied here), and, at the same time, problems derived from a possible ' $\mathrm{N}$ rob'. As expected, the positive effect of a complete fertilizer on plant growth and nutrition was higher than with the sole application of urea (Tables 5 and 6). Treatment IF yielded a total dry matter production twice that obtained in treatment $U$, the same amount of $\mathrm{N}$ per pot being applied in both.

The high rate of compost application $(2.5 \% \mathrm{w}: \mathrm{w}$, treatment $\mathrm{C})$ caused the lowest dry matter production (especially in the first cut, in which it was around $50 \%$ lower than that of the control) (Table 5). In the second cut, the two treatments yielded similar dry matter productions, but it is necessary to bear in mind that the ryegrass (sown at a rate of $1 \mathrm{~g}$ seed pot $^{-1}$ ) accomplished a greater initial consumption of nutrients in the control than in treatment $C$.

The application of compost together with $\mathrm{IF}$ or urea (treatments $\mathrm{C}+\mathrm{IF}$ and $\mathrm{C}+\mathrm{U}$ ) did not cause any negative effect on plant growth, despite the compost's (and fertilizers') being applied at sowing. It can be seen (Table 5) that these treatments yielded similar (treatment $\mathrm{C}+\mathrm{IF}$ ) or higher (treatment $\mathrm{C}+\mathrm{U}$ ) dry matter production in the first cut than did treatments IF and U. Nevertheless, the consumption of fertilizers by plants of the first cut could reduce the dry matter production of the

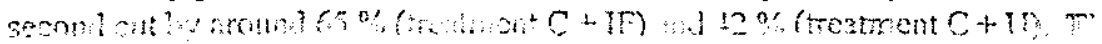


TABLE 5. Mean values of dry matter production (above-ground part) and nutrient accumulation (on a dry matter basis) in the above-ground part of the ryegrass.

\begin{tabular}{lllllllll}
\hline $\begin{array}{l}\text { Treat- } \\
\text { ment }\end{array}$ & \multicolumn{2}{c}{$\begin{array}{c}\text { Dry matter production }\left(\mathrm{g} \mathrm{pot}^{-1}\right) \\
\text { 1st cut }\end{array}$} & 2nd cut & Total & $\mathrm{N}$ & $\mathrm{P}$ & $\mathrm{K}$ & $\mathrm{Mn}$ \\
\hline Control & $0.72 \mathrm{~b}^{*}$ & $0.24 \mathrm{a}$ & $0.96 \mathrm{a}$ & $18.9 \mathrm{a}$ & $1.8 \mathrm{a}$ & $42.1 \mathrm{a}$ & $0.18 \mathrm{~b}$ \\
IF & $2.13 \mathrm{e}$ & $2.88 \mathrm{~d}$ & $5.01 \mathrm{c}$ & $226.0 \mathrm{~d}$ & $16.0 \mathrm{e}$ & $293.6 \mathrm{e}$ & $0.81 \mathrm{e}$ \\
$\mathrm{U}$ & $1.22 \mathrm{c}$ & $1.33 \mathrm{c}$ & $2.55 \mathrm{~b}$ & $111.0 \mathrm{c}$ & $4.1 \mathrm{~b}$ & $131.5 \mathrm{~b}$ & $0.45 \mathrm{~d}$ \\
$\mathrm{C}$ & $0.35 \mathrm{a}$ & $0.23 \mathrm{a}$ & $0.57 \mathrm{a}$ & $10.2 \mathrm{a}$ & $1.3 \mathrm{a}$ & $21.3 \mathrm{a}$ & $0.07 \mathrm{a}$ \\
$\mathrm{C}+\mathrm{IF}$ & $2.11 \mathrm{e}$ & $0.73 \mathrm{~b}$ & $2.83 \mathrm{~b}$ & $96.2 \mathrm{cb}$ & $10.1 \mathrm{~d}$ & $167.5 \mathrm{~d}$ & $0.27 \mathrm{c}$ \\
$\mathrm{C}+\mathrm{U}$ & $1.58 \mathrm{~d}$ & $0.92 \mathrm{bc}$ & $2.51 \mathrm{~b}$ & $89.1 \mathrm{~b}$ & $5.5 \mathrm{c}$ & $137.6 \mathrm{bc}$ & $0.29 \mathrm{c}$ \\
\hline
\end{tabular}

*Values followed by the same letter in the same column do not differ significantly $(\mathrm{P}<0.05)$.

reduction was not found in treatments $\mathrm{IF}$ and $\mathrm{C}$ (Table 5), both using a twofold amount of fertilizer.

In general, treatments including IF yielded the highest total dry matter productions recorded (two cuts). This was especially so in the case of treatment $I F$, which led to the highest production (5.01 $\mathrm{g} \mathrm{pot}^{\mathrm{I}}$, Table 5). As a consequence, this treatment yielded the highest amounts of accumulated nutrients in the above-ground part of the ryegrass. Nevertheless, urea seemed to be an adequate source of $N$ for fortifying composts, since application (without $\mathrm{P}$ and $\mathrm{K}$ ) yielded a similar dry matter production to that obtained in treatment $\mathrm{C}+\mathrm{IF}$.

TABLE 6. Mean values of nutrient accumulation (on a dry matter basis) in the above-ground part of the ryegrass (total of the three cuts).

\begin{tabular}{|c|c|c|c|c|c|c|c|}
\hline \multirow{2}{*}{$\begin{array}{l}\text { Treat- } \\
\text { ment }\end{array}$} & $\overline{\mathrm{N}}$ & $\mathbf{P}$ & K & $\mathrm{Ca}$ & $\mathrm{Mg}$ & $\mathrm{Mn}$ & $\mathrm{Zn}$ \\
\hline & \multicolumn{7}{|c|}{$\left(\mathrm{mg} \mathrm{pot}{ }^{-1}\right)$} \\
\hline 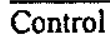 & 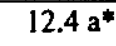 & $1.8 \mathrm{a}$ & $39.1 \mathrm{a}$ & $18.3 \mathrm{a}$ & $2.6 \mathrm{a}$ & - & 0.05 \\
\hline & & & & & & & $9 \mathrm{a}$ \\
\hline & $89.2 \mathrm{c}$ & $.9 \mathrm{C}$ & $9.6 \mathrm{c}$ & 42.0 & $9.4 \mathrm{~b}$ & c & .16 \\
\hline & $17.4 \mathrm{~d}$ & 0 & $d$ & 55.9 & $12.6 \mathrm{c}$ & $3 \mathrm{~d}$ & 0.27 \\
\hline $\mathrm{j}_{3}$ & $9.9 \mathrm{f}$ & 1 & $9 \mathrm{~d}$ & $71.4 \mathrm{e}$ & $15.9 \mathrm{~d}$ & $0.57 \mathrm{~d}$ & $0.27 b c$ \\
\hline & $96.1 \mathrm{c}$ & $9 \mathrm{c}$ & $6.3 \mathrm{~d}$ & 40. & $9.4 \mathrm{~b}$ & $0.47 \mathrm{~cd}$ & $0.30 \mathrm{~cd}$ \\
\hline & $9.8 \mathrm{e}$ & $18.6 \mathrm{f}$ & $25.8 \mathrm{e}$ & 50.3 & $13.0 \mathrm{c}$ & $0.69 \mathrm{e}$ & $0.39 \mathrm{de}$ \\
\hline & $5.1 \mathrm{~g}$ & $3 \mathrm{~cd}$ & $5.7 \mathrm{e}$ & $57.3 \mathrm{~d}$ & $15.1 \mathrm{~d}$ & $0.71 \mathrm{e}$ & $0.44 \mathrm{e}$ \\
\hline
\end{tabular}

*Values followed by the same letter in the same column do not differ significantly $(\mathrm{P}<0.05)$. 
The compost tended to enhance (though only slightly) $\mathrm{P}$ and $\mathrm{K}$ uptake by the ryegrass, since, for a similar total dry matter production, the treatment $\mathrm{C}+\mathrm{U}$ caused a significantly greater accumulation of $P$, and also a (non-significantly) greater accumulation of $\mathrm{K}$ than did treatment $\mathrm{U}$ (Table 5). This effect was especially evident in the second cut (data not shown). In contrast, and also for similar dry matter productions, treatments $\mathrm{C}+\mathrm{IF}$ and $\mathrm{C}+\mathrm{U}$ reduced the $\mathrm{Mn}$ accumulation around $40 \%$ and $35 \%$, respectively, compared with that recorded in treatment $U$.

This could imply the existence of an antagonism (Jarrell and Beverly, 1981) in the Mn uptake, derived from compost presence. Depressive effects of organic matter on Mn uptake by plants have been reported in the literature (Wallace and Wallace, 1983).

\section{Compost Correction with Increasing Doses of Urea (Supplemented with Phosphorus and Potassium)}

In order to minimize possible problems derived from a restricted $\mathrm{O}_{2}$ supply, the fraction $<10 \mathrm{~mm}$ was used when correcting the immature, but well particulated composts studied here. Moreover, in this experiment the compost was applied at a rate of $1.5 \%$ (not $2.5 \%$ ) and perlite was included in the substrate, as described above, to prevent soil compaction as much as possible.

In this experiment, ryegrass was cut three times in a period of 100 days (in the above experiment it could be cut only twice, in the same period, due to its poor growth in the control and treatment $\mathrm{C}$ ). The maximum dry matter production recorded in this experiment was around $5 \mathrm{~g} \mathrm{pot}^{-1}$ (treatments $\mathrm{U}_{2}, \mathrm{U}_{3}, \mathrm{C}+\mathrm{U}_{2}$, and $\mathrm{C}$ $+U_{3}$ : Figure 1), similar to that obtained in the treatment IF of the previous assay (Table 5). This corroborates the suitability of using urea as a source of $\mathrm{N}$ when correcting composts.

Under the conditions of this experiment, compost (treatment C) always led to higher dry matter production than did the control, despite its application at sowing. On the other hand, the highest doses of urea (treatments $U_{3}$ and $C+U_{3}$ ) did not have any positive effect on the dry matter production, when compared with treatments $\mathrm{U}_{2}$ and $\mathrm{C}+\mathrm{U}_{2}$ (Figure 1).

For similar dry matter productions, treatments $\mathrm{C}+\mathrm{U}_{2}$ and $\mathrm{C}+\mathrm{U}_{3}$ tended to cause higher above-ground accumulations not only of $\mathrm{N}, \mathrm{K}$, and $\mathrm{Zn}$ than did treatments $\mathrm{U}_{2}$ and $\mathrm{U}_{3}$, but also of $\mathrm{Mn}$ (Table 6 ). This could indicate that the above-mentioned depressive effect of compost on Mn uptake could be influenced by, apart from the higher dose of compost applied, the compaction of the substrate. On the other hand, urea (fortified with $\mathrm{P}$ and $\mathrm{K}$ ) seemed to enhance $\mathrm{Mn}$ accumulation to some extent, while compost presence tended to depress $\mathrm{Ca}$ accumulation (Table 6).

Except for $\mathrm{Ca}$, and bearing in mind that the $\mathrm{Ca}$ levels were always satisfactory for covering plant requirements, the application of compost (under the conditions of this experiment) did not interfere in plant nutrition, despite its immaturity and despite its being applied at sowing. Therefore, it seems particularly important not 


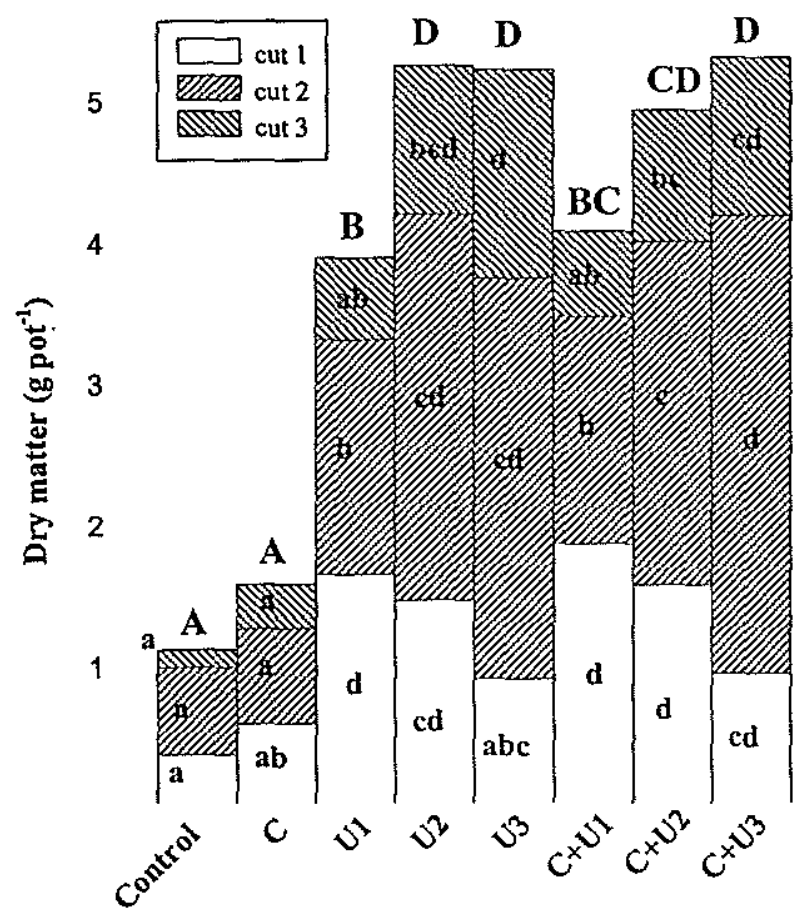

TREATMENTS

FIGURE 1. Dry matter production of the ryegrass in the different treatments. Bars with the same letter, for each cut (small letters) or in total (capital letters), do not differ significantly.

to restrict aeration of the substrates when using this kind of well particulated compost. Avnimelech et al. (1993) have pointed out that a surface application, or a very shallow mixing with the soil, may ensure a better plant response to compost application.

To avoid an occasional ' $\mathrm{N}$ rob', adequate combinations with urea (fortified with $\mathrm{P}$ and $\mathrm{K}$ when possible) may be an advisable practice when using these composts. This practice would also avoid using large doses of composts for covering crop requirements. In this experiment, in which the compost did not seem to cause any problem of ' $\mathrm{N}$ rob', treatment $\mathrm{C}+\mathrm{U}_{1}$ (compost:urea ratio of about 50:1) led to a reasonable dry matter production of ryegrass (a species very demanding for $\mathrm{N}$ ), not significantly different to that of treatment $\mathrm{C}+\mathrm{U}_{2}$ (compost:urea ratio of $25: 1$, which vielded one of the maximum productions recorded). 
This seems to indicate that for a normal agricultural dose of composts (i.e., $10 \mathrm{t}$ $\mathrm{ha}^{-1}$ ), recommended for soils in the South of Spain, generally with low organic matter contents, but usually founded incompletely stabilized, the addition of around $200 \mathrm{~kg}$ urea ha-1 may be sufficient not only to avoid problems, but also to obtain good results for crop establishment and the first steps of growth. Additional fertilization will depend on each particular situation. The results we are obtaining in the field (in preparation) corroborate this assertion.

\section{CONCLUSIONS}

Municipal solid waste compost from 'Villarrasa' facility showed non-stabilized substances which could indicate immaturity, and bioassays of germination proved its instant toxicity for plants. When compost was incorporated into soil, the emergence of plants was not affected, but negative effects were shown by the plantlets' fresh weight. A dose of $200 \mathrm{~kg}_{\text {urea }} \mathrm{ha}^{-1}$ was sufficient to avoid problems at the first stages of the crop.

\section{ACKNOWLEDGMENTS}

This work was supported by the Agencia de Medio Ambiente of the Junta de Andalucía, Spain.

\section{REFERENCES}

Ashwell, G. 1966. Complex carbohydrates. pp. 93-95. In: E.F. Neufeld and V. Ginsburg (eds.), Methods in Enzymology. Vol. VIII. Academic Press, New York, NY.

Avnimelech, Y., A. Cohen, and D. Shkedy. 1993. Can we expect a consistent efficiency of municipal waste compost application? Compost Sci. Util. 1:7-14.

Barker, A.V. 1997. Composition and uses of compost. pp. 140-162. In: J.E. Rechligh and H.C. Mackinnon (eds), Agricultural Uses of By-products and Wastes. ACS Symposium Series 668, Chapter 10. American Chemical Society, Washington, DC.

De Bertoldi, M., M.P. Ferranti, P. L'Hermite, and F. Zucconi (eds.). 1987. Compost: Production, Quality and Use. Elsevier Applied Science, London, England.

De Haan, S. 1981. Results of municipal waste compost research over more than fifty years at the Institute for Soil Fertility at Haren/Groningen, The Netherlands. Neth. J. Agric. Sci. 29:49-61.

Déportes, I., J.L. Benoit-Guyod, and D. Zmirou. 1995. Hazard to man and the environment posed by the use of urban waste compost: A review. Sci. Total Environ. 172:197-222. 
Fricke, K., W. Pertl, and H. Vogtmann. 1989. Technology and undesirable components on compost of separately collected organic wastes. Agric. Ecosyst. Environ. 27:463-469.

Genevini, P.L., F. Adani, D. Borio, and F. Tambone. 1997. Heavy metal content in selected European commercial composts. Compost Sci. Util. 5:31-39.

Gies, G. 1992. Regulating compost quality in Ontario. BioCycle 33:60-61.

Harada, Y. and A. Inoko. 1980. The measurement of the cation-exchange capacity of composts for the estimation of the degree of maturity. Soil Sci. Plant Nutr. 26:127-134.

Hileman, L.H. 1982. Fortified compost product shows promise as fertilizer. BioCycle 23:43-44.

ISTA (International Seed Testing Association). 1985. International rules for seed testing: Rules 1985. Seed Sci. Technol. 13:299-355.

Jarrell, W.M. and R.B. Beverly. 1981. The dilution effects in plant nutrition studies. pp. 197-224. In: N.C. Brady (eds.), Advances in Agronomy. Vol. 34. Academic Press, New York, NY.

Mathur, S.P., G. Owen, H. Dinel, and M. Schnitzer. 1993. Determination of compost biomaturity. I. Literature review. Biol. Agric. Hort. 10:65-85.

Murillo, J.M., F. Cabrera, and R. López. 1993. Effect of beet vinasse on germination and seedling performance of ryegrass (Lolium multiflorum Lam cv. Barwoltra). J. Sci. Food Agric. 61:155-160.

Murillo, J.M., R. López, F. Cabrera, and P. Martín-Olmedo. 1995a. Testing a low-quality urban compost as a fertilizer for arable farming. Soil Use Mgt. 11:127-131.

Murillo, J.M., F. Cabrera, R. López, and P. Martin-Olmedo. 1995b. Testing low-quality urban composts for agriculture: Germination and seedling performance of plants. Agric. Ecosyst. Environ. 54:127-135.

Sikora, L.J. 1996. Effect of compost-fertilizer blends on crop growth. pp. 423-430. In: M. De Bertoldi, P. Sequi, B. Lemmes, and T. Papi (eds.), The Science of Composting. Part 1. Blackie Academic \& Professional, Glasgow, Scotland.

Smith, W.H. 1996. Utilizing composts in land management to recycle organics. pp. 413422. In: M. De Bertoldi, P. Sequi, B. Lemmes, and T. Papi (eds.), The Science of Composting. Part 1. Blackie Academic \& Professional, Glasgow, Scotland.

Soliva, M., F. Giró, and S. Manzano. 1993. Nitrogen lost during MSW composting at two facilities in Spain. Compost Sci. Util. 1:23-26. 
Vogtmann, H., K. Fricke, and T. Turk 1993. Quality, physical characteristics, nutrient content, heavy metals and organic chemicals in biogenic waste compost. Compost Sci. Util. 4:69-87.

Wallace, A. and G.A. Wallace. 1983. Zinc chelates inhibited uptake of copper and manganese or is it chelating agent inhibition? Differential zinc accumulation in primary leaves. J. Plant Nutr. 6:559-562.

Zucconi, F. and M. De Bertoldi. 1987. Specifications for solid waste compost. BioCycle 28:56-61.

Zucconi, F., M. Forte, A. Monaco, and M. De Bertoldi. 1981. Biological evaluation of compost maturity. BioCycle 22:27-29.

Zucconi, F., A. Monaco, M. Forte, and M. De Bertoldi. 1985. Phytotoxins during the stabilization of organic matter. pp. 73-86. In: J.K.R. Gasser (ed.), Composting of Agricultural and Other Wastes. Elsevier Applied Science Publishers, London, England. 